\title{
Darcy, Heathcliff, and the Drama in Solitary Reading
}

\author{
Justin Bermudez, Simon Fraser University
}

I'm dramatic. I wouldn't call myself a show-boater or someone who demands attention, mind you. For me, it's more of an internal drama that I've always seemed to possess, an emotional root within me that dictates my sense of myself. I love this, but it is something I hid away from others when I was younger. Books gave me the space to explore this dramatic part of myself, free of judgement.

While books eventually gave me this, film was my gateway. Ever since I was young, I remember the 1995 BBC Pride and Prejudice being on in the background of my home. In 2005 when Joe Wright's film adaptation came out, though, I found my very own love of Austen. The film had atmosphere, it had family dynamics, it had God-Damn-Handsome-Ass-Mr. Darcy, and most importantly, it was very, very, romantic. I indulged in this movie and its atmosphere for years, and it is ultimately what opened me up to the idea of getting lost within a story.

After this romantic experience, I made a huge effort to finally read Pride and Prejudice, and this really is when reading became a part of who I am today. It isn't because I simply read the book, or even really understood the novel like I did with the adaptations, it's more that I found something in the novel that allowed me to feel emotions that I considered too dramatic to experience with others. Sure, I didn't understand everything I was reading that summer, or for a long time to come, but reading this book became a place for me to explore a story, and my inner self, by myself; an emotional space I experienced without fear. With Darcy, I had a wonderful summer. I experienced enjoyable thoughts, I played out achingly romantic vignettes, and even experienced moments of sad misunderstanding that I found it hard to deal with. Reading gave me these feelings, and I soon became hooked on the possibilities of books.

The condition of my books is a testament to this new type of exploration. Early on I started writing in books. I scribbled names, wrote silly things in the 
margins, and added the odd smile or frown next to passages I felt were emotionally important to me. I dog-eared books until they became ruined and took them with me everywhere until they were filthy with overuse. I have a prized mass-market paperback version of Pride and Prejudice of absolutely no scholarly worth, but it is so sun-faded, yellowed, and well-loved that I could never imagine leaving it behind for something new.

I should mention that reading, and perhaps more importantly storytelling, was always part of my life before that summer, but this was always more of a family activity. The bedroom or sofa is where we would read stories out loud as a family, and these moments are some of my fondest as a child. Stand-out bedtime stories like Bread and Jam for Frances by Russell Hoban and Not the Piano, Mrs. Medley by Evan Levine were favorites for their comforting playfulness. Alfie Gets in First by Shirley Hughes also always made us laugh because of the titular Alife sharing a namesake with our father. As we grew up, we took turns reading lengthier books aloud as a group: the first four books in the Harry Potter series for example, as well as Lois Lowry's science fiction novel The Giver. Around this age I started branching out into my own reading, though, and it's then that Elizabeth Bennett popped in to let me know that reading could be a personal escape and a place for solitary thought.

At this time, none of my friends seemed interested in reading, and none had any real desire to share this hobby with me. And honestly, I don't blame them. As young people we could easily run and play outdoors, but we also had that easy luxury of watching television or movies whenever given the chance. Compared with reading, outdoor adventures and blockbusters always won out. Movies therefore became the thing I shared with my friends, not books. Looking back, I think this made me upset. Like I said, reading was a growing emotional space for me, even if it was largely solitary and personal. However, as a pre-teen, what's more important than introducing people to a place you express yourself in, sharing what you value and having others understand who you are growing into? I had a hard time with these changing feelings, and, as much as books were a personal space just for me, I think I felt a desire to start sharing this emotional part of me with others.

This reading space was emotional, but it was also enjoyable. Reading began to highlight where my passions were, and I soon found my growing interests revolving around history, literature, and the past. As a pre-teen, my first real exposure to the past as a concept came from both Austen and movies, a concept

ENGL487W - Summer 2021 
that still fascinates and informs my interests to this day. As an extension to this new fascination, in late elementary school I became obsessed with a series of books called The Royal Diaries. Blending both fact and fiction, these books depicted the often turbulent lives of different female leaders throughout history. I read about Cleopatra VII, Queen Seondeok from 595 AD Korea, Marie Antionette, and Anastasia Nikolaevna of Russia. Looking back at these books and their writing now... well, it's not groundbreaking. However, I loved these books, so try telling my younger self that these were anything but fantastic! These books represented both history and culture to me, but more importantly they became a way for me to experience perspective in a new way that felt both very personal and - you guessed it - emotional.

As a cis gay man of Spanish, Swedish, and Indigenous ancestry, I can honestly say I had nothing in common with any of the Royal Diaries characters, and, shockingly, I still have a very different existence to that of these women now. I'm positive that a younger me either glorified or misconstrued these figures in some way, probably due to my own emotional response to the stories and how I tended to be swayed by my feelings rather than analytical thought. Nevertheless, back then, these stories felt real. This sounds silly to stress, because they are about very real figures, but these fictional narratives felt authentic enough that they emotionally affected my own growing viewpoint about different people and their lives. I wanted to connect with the stories and voices that I was reading about, and I think the Diaries series really made me realize that books can truly link people together in this profound way.

From that point on, I think it's fair to say that I moved into the emotionally dense times of high school, and in those years reading moved to the hidden peripheral world where teenagers lock up their dark secrets (and better yet, their feelings). As an extension from Austen, I started to read the Brontës, falling in love with Heathcliff and despising Mr. Rochester. Heady with their own implied drama, these books became personal favourites of mine in the dark moody years of my teens. During those years my spare time was peppered with personal readings like these, but reading soon began to dwindle out, as even at school I began only to read what and when it was required. I had drama classes going on, community theater, I was attempting to forge new interests and make new friends; times were busy. And, like I mentioned, my friends were never readers, and when high school asks you to be more social and "with it" - sometimes at the cost of yourself - you often abandon your emotional life rafts in hopes of finding

ENGL487W - Summer 2021 
something that better connects you with other people. I did keep Darcy and Heathcliff around, however.

I have since realized that abandoning something you love isn't always the most fulfilling. High school ended, the mirage of outside "stuff" that teens get wrapped up in finished, and I found my way back to dramatically being me with books. And for the most part, I talk about books more, and the fear that my loved ones would condemn my overly dramatic indulgence in novels is gone. I share novels with my friends and family now, and thankfully, they also happily want to do the same. Everyone knows how much I love to get lost in a book, and I find myself sharing more and more of myself with others, thanks to opening up space I largely considered solitary. Books are still a place for me to over-emotionally contemplate things, even if it's just me wondering about Mr. Darcy's brooding thoughts and feelings. For the most part, though, I happily and wholeheartedly now share that space with others.

(c) $(9)($ This work is licensed under a Creative Commons Attribution-
NonCommercial-NoDerivatives 4.0 International License.

(C) Justin Bermudez, 2021 